\title{
Teacher's Digital Fluency: a New Competence for Foreign Language Teaching
}

\section{A fluência digital do professor: uma nova competência para o ensino de línguas estrangeiras}

Isis da Costa Pinho*

Universidade do Vale do Rio dos Sinos (UNISINOS)

São Leopoldo - Rio Grande do Sul/Brasil

Marilia dos Santos Lima**

Universidade do Vale do Rio dos Sinos (UNISINOS)

São Leopoldo - Rio Grande do Sul/Brasil

\begin{abstract}
This paper reports on a case study research focusing on digital fluency as a new competence for teaching foreign languages through technology. The data were generated on a training course having as its main purpose the investigation of pre-service and in-service teachers' perceptions about the relevance of digital fluency and the pedagogical use of digital technologies for foreign language (FL) teaching and learning. The trainee teachers were asked to work in groups with the purpose of exploring Windows Movie Maker software in order to create a movie addressing the importance of digital fluency and the potential of this digital tool in FL teaching and learning. The results suggest that digital fluency was considered a necessary competence for the creation of more attractive and dynamic lessons that motivate meaningful FL production.
\end{abstract}

KEYWORDS: digital fluency; competence; teacher education; foreign language.

RESUMO: O presente artigo trata de um estudo de caso com foco na fluência digital como uma nova competência para o ensino de línguas estrangeiras (LEs) por meio da tecnologia. A partir de dados gerados em um curso de formação de professores, investiga-se a percepção de professores pré-serviço e em serviço sobre a relevância da fluência digital e do uso pedagógico de ferramentas digitais para o ensino-aprendizagem de línguas estrangeiras. Foi proposto que os professores explorassem a ferramenta Windows Movie Maker para a produção de um filme

* isis.letras@yahoo.com.br

**marilialim@unisinos.br 
com foco na fluência digital e nas potencialidades dessa ferramenta para o ensino e a aprendizagem de LEs. Os resultados sugerem que a fluência digital foi considerada uma competência necessária para a criação de aulas mais atraentes e dinâmicas que motivem a produção significativa de línguas estrangeiras.

PALAVRAS-CHAVE: fluência digital; competência; formação de professores; língua estrangeira.

\section{Introduction}

The Information Society, a term originated in economy, is a global phenomenon that consists of changes in organization and production, in which the effective participation of each country depends not only on its knowledge and education, but especially on its scientific and technological development. To compete in the international market, the Brazilian government seeks to promote universal access to technology, as well as the development of competences required by the new economy through computer-based teaching training programs. These training programs for the use of technology in education are considered to be essential for the proper pedagogical use of information and communication technologies' (ICTs) potential, being also a multiplication factor of competences (BRASIL, 2000).

Thus, education is faced with the great challenge to promote competences for the inclusion of students in a virtual community that revolves around not only the consumption and supply of goods, services and information, but also the production, research and sharing of knowledge and innovations technology. In addition, it is necessary to consider the importance of preparing foreign language $(\mathrm{FL})$ teachers for the pedagogical use of digital tools in order to foster computer-supported teaching and learning.

Grounded in the areas of FL teaching and learning and information technology in education, this study aims to address the importance of digital fluency and the pedagogical use of digital tools for the qualification of FL teachers' performance and the improvement of language education, from the perspective of the teachers themselves on this matter.

With this objective in mind, this paper tries to integrate sociocultural theory principles, studies on information technology in education and on competence as a theoretical basis to discuss what knowledge, competence and attitude FL teachers need to develop in the use of technology for teaching. It should be noted, though, that digital fluency for education involves not only knowing digital tools, but rather to make a critical, creative, autonomous and authoring use of them, blending their potentials to FL teaching and learning goals. 
This theoretical background allowed for the focus on pre-service and in-service teachers' production generated on a training course on the use of digital technology for FL teaching and learning held in 2011 at a federal university in southern Brazil. Data analysis sought to answer the following questions: (1) What are the perceptions of FL teachers in initial and continuing training about the importance of digital fluency for their performance and the pedagogical potential of the digital tool Windows Movie Maker? (2) What are the participants' perceptions about the benefits of developing a collaborative reflective task, having Windows Movie Maker in their training?

\section{Theoretical Framework}

The use of technology today is seen as a key knowledge for the participation in the Information Society, which makes its presence a requirement for a high quality FL teaching curriculum. Added to this, as Blake (2008) points out, the large number of students entering universities in addition to a new profile of learners whose primary means of communication involves computer and mobile technologies demand for a reformulation in the way language teaching has been developed.

This new education framework brings challenges to FL teachers' performance, taking into account that they need to develop a level of digital fluency that responds to the complexity of their pedagogical practice in computer-based teaching. Therefore, it is vital that teachers get updated on continuing training courses in order to develop knowledge, competences and attitudes to effectively combine teaching and learning concepts and goals with digital technologies in their practice.

On the other hand, the understanding of what FL teachers' digital fluency is all about first requires the grasp of the competence concept. According to Perrenoud (1999, 2000a, 2000b, 2002, 2004), competence is not only the set of knowledge, skills (savoir faire) and attitudes, but rather the mobilization, integration and orchestration of resources for a situated action that transforms knowledge through complex mental operations. In line with this definition, Zabala and Arnau (2010) consider competence an effective intervention in solving situations, in which attitudinal, procedural and conceptual components are mobilized at the same time and in an interrelated fashion.

Hence, in the present study teacher's competence is conceived as the development of knowledge, skills and attitudes about teaching and learning through technology by mobilizing problem solving situations that arise in 
teaching practice (PERRENOUD, 1999, 2000a, 2000b, 2002, 2004; DOLZ; OLLAGNIER, 2004; ZABALA; ARNAU, 2010).

Problem situation is defined by Perrenoud (2000b) as the resolution of an obstacle to learning by means of negotiation, strategies and hypotheses' creation. It is worth pointing out here that one of the most important features in a task is to present challenges. Thus, this concept brings a new perspective to education since it highlights the relevance of providing challenging tasks that contextualize content and demand the mobilization of competences to resolve situations related to learners' social practices.

In the digital era, the role of FL teaching should be to promote both communication skills and digital fluency, including in this way learners in the Information Society. In this regard, it is observed that Web 2.0 requires of its users fluency in the production, modification and sharing of content, as well as their participation in virtual communities going beyond basic knowledge and skills. The book Information Society: Green Book (free translation of the original title Sociedade da Informação: Livro Verde in BRASIL, 2000, p. 45) discusses the relevance of education through technology and claims that:

[...] to educate in an Information Society means much more than training people to information and communication technology's use: it is investing in competence building large enough to enable them to have an effective performance in the production of goods and services, to make decisions based on knowledge, to operate with fluency new media and tools in their work, as well as to creatively apply new media, either in simple and routine uses or in more sophisticated applications. ${ }^{1}$

Thus, to actually participate in the information society, both teachers and students need to develop digital fluency in the use of technology (NATIONAL RESEARCH COUNCIL, 1999).

A study carried out in 1999 by the National Science Foundation in the United States titled FITness: Being fluent with Information Technology focused on essential competences for the participation in the Information Society. The committee used the term fluency from the definition of Yasmin B. Kafai, who considers digital fluency as "the ability to reformulate knowledge, to express oneself creatively and appropriately, and to produce and generate information

\footnotetext{
${ }^{1}$ Free translation from the authors.
} 
(rather than simply to comprehend it)" (NATIONAL RESEARCH COUNCIL, 1999, p. VIII). It follows from this definition that digital fluency is considered a dynamic competence that requires an adaptation to technology for the transformation and acquisition of new knowledge that occurs throughout life.

The digital fluent should, therefore, have a critical eye towards the information and content shared on Web 2.0, knowing to select safe and reliable sources. It is also important to be proactive and curious, seeking to update his knowledge through research and exploration of new digital tools. Also, he needs to be flexible, being open to new ideas of technology use for the production of knowledge and technology.

Based on the preceding discussion, in this study digital fluency is considered to be, in general terms, a competence in which there is the mobilization, adaptation and transformation of knowledge, skills and attitudes for appropriate, creative, autonomous and authoring use of technology (BONILLA, 2001; NATIONAL RESEARCH COUNCIL, 1999).

Thus, the teaching practice complexity requires from the FL teacher the development and integration of competences to work on several levels. Among the essential competences for a successful teaching practice listed by Perrenoud (2000b), what stands out is the knowledge of organizing and guiding learning situations; using new technologies; and managing their own continuing training. This indicates the challenges technology offers for FL teachers that need to know how to plan and create meaningful tasks, using digital tools' pedagogical potential. Still, it is essential that teachers keep updated on the possibilities of ICTs uses and new technologies.

Teacher's digital fluency is a competence that seeks to meet the complexity of teaching practice in teaching through technology. Hence, it is related to the integration of knowledge, skills and attitudes about the potential of digital tools and virtual environments in lesson planning, creation and mediation of tasks, and evaluation of performance and students' skills.

Furthermore, Blake (2008) points out that beyond developing a computer functional competence, by knowing how to use digital tools, FL teachers should build critical competence, grasping the tools' context of use, and rhetoric competence, understanding how these tools can improve teaching and promote learning. Blake's point of view comes into line with Perrenoud's (2000b), who argues that in order to manage learning situations effectively, teachers should above expertise know how to identify and enhance their own skills within their profession and in other social practices. 
According to Lamy and Hampel (2007) and Leffa (2005; 2006), language teachers must be reflective technology practitioners, mastering the ever changing digital tools and experiencing the online classroom like their students. So understanding how students use and learn through technology enables teachers to consciously approach its affordances for FL teaching and the purpose of its use. Furthermore, studies have indicated a need to investigate the effects of collaborative learning as well as the use of general application software for language teaching (PLASS; JONES, 2005; JONASSEN et al., 2005; KESSLER, 2010). Thus, the present research looks at FL teachers' perceptions about the importance of digital fluency and the pedagogical use of digital tools for their performance as they make a collaborative and reflective use of Windows Movie Maker on this topic.

According to Perrenoud (2000b, p. 125), "technologies dramatically transform not only our ways of communicating, but also to work, to decide and think". Furthermore, the author emphasizes the importance of promoting an information technology culture with the intended use of digital technologies in the classroom, and warns that the use of technology as just a marketing ploy is a disservice to education.

Hence, it is not the use of technology per se that will lead to a successful teaching, but rather the way it is used in the exploitation of content. Besides, it is necessary to have a clear theoretical basis in order to consciously decide what, when, and how a digital tool can be used for teaching (BLAKE, 2008). In this new pedagogical paradigm, teachers should foster a collaborative perspective in the use of technology as a tool for language learning in the production of content by creating and managing a learning community where social interaction supports information exchange, knowledge construction, and competence building (PINHO, 2012; MENEZES, 2010; POLONIA, 2003).

Based on the premise that learning is mediated by social interaction and cultural artifacts as language and computers, this study explores sociocultural theory principles (VYGOTSKY, 1978; 2003; LANTOLF, 2000; 2006) that conceive language learning to be a process that takes place through the collaborative nature of interaction, in which negotiation of form and meaning leads to improvement of FL communication (SWAIN, 1985; 2006).

In sociocultural theory, the potential for learning (Zone of Proximal Development) arises from interaction with others (teacher, tutor, peers and digital tools), and the joint construction of knowledge (interpsychological activity) is internalized by individuals (intrapsychological activity) contributing to their cognitive and social development. This process is mediated by 
language as a cognitive activity and product of thought which also serves as a supporting tool (scaffolding) between learners (VYGOTSKY, 1986; LANTOLF, 2000; SWAIN, 2001; HALL, 2001; WOOD; BRUNER; ROSS, 1976).

Here the relevance of Merrill Swain's $(1985 ; 2001)$ studies is noteworthy. Her studies show that input in a second language (or foreign language) acquisition context is necessary but not sufficient for achieving higher levels of language fluency. It is, thus, vital to go beyond input exposure occasions creating opportunities for language learners to exploit their language knowledge and skills in the production of meaning. At this point, collaboration in the realization of a collective task becomes a motivating source for language learning in the way that negotiation and mutual assistance generate a comprehensible output for the construction of linguistic knowledge (LIMA, 2011; LIMA; COSTA, 2010; PINHO; LIMA, 2010).

Based on a sociocultural perspective, it is understood that the process of FL teaching and learning occurs through tasks centered on language exploration, interaction and production in situations where collaboration and negotiation of meaning support communication through technology (VYGOTSKY, 1978; 2003; LANTOLF, 2000; 2006; SWAIN, 1985; 2006; WOOD; BRUNER; ROSS, 1976). In such contexts, technology, apart from being a pedagogical tool, also becomes a learning tool being explored by the students in the production of digital material.

Regarding meaningful language learning, Paiva (1999) adds that:

Computer-mediated Foreign Language learning offers more meaningful contexts of language use to students, increases learning opportunities, encourages autonomous learning, accommodates different rhythms and needs, facilitates access to authentic material and goes beyond the classroom walls providing interaction with people worldwide [electronic version]. ${ }^{2}$

To promote learning, teachers should involve the students in the interaction with different media and information sources, fostering their participation in virtual communities, the development of joint projects, and the negotiation and construction of knowledge about the world, themselves and their learning (BRASIL, 2007).

${ }^{2}$ Free translation from the authors. 
Blake (2008) also speaks about the benefits of computer use for FL learning, stating that it is a motivating and more comfortable environment for language production, since it amplifies the focus on linguistic forms, allows the creation of learning networks, and leads learners to engage more often, with more confidence and enthusiasm in comparison to traditional classrooms. Added to this, technology can promote autonomy and creativity, enabling a multimedia expression of meaning.

In relation to autonomy, Benson (2001) considers it to be one's own individual ability to control learning derived from a constant process of knowledge construction and ressignification based on collective and individual previous decision-making experiences in solving problems. The individual's freedom to make decisions, he states, must respond to the social environment. Hence, Nicolaides (2003) argues that autonomy involves using knowledge to modify responsibly the social environment. An autonomous learner, according to Nicolaides (2003), must know how to define his/her goals, identify him/ herself as a responsible agent in the search and acquisition of knowledge, to establish the methods for pursuit of knowledge inside and outside academia.

Autonomy would therefore be the continuous process of forming an intellectual identity through engagement in experiences of awareness, decisionmaking and responsibility of a learner to him/herself before the group and as a group before him/her. In this sense, teachers' autonomy is not a product to be achieved, but rather a continuous process of taking transformative actions of learning and teaching driven by curiosity about the new and the critical reflection of their own practice. It is an active positioning as their own learning process in creating strategies for solution of problems encountered by the interest in new knowledge and new goals to achieve. The development of autonomy is building the teachers' own voice before their participation in their intellectual and social growth in their culture and group (PINHO, 2008).

The concept of autonomy can also be found in the sociocultural theory as regulation or control over behavior (VYGOTSKY, 1987) as the ultimate goal that guides and characterizes all learning process. Here autonomy is seen closely connected with the idea of authorship, since, as Leffa (2005) argues, one of the big challenges FL teachers have to face in order to achieve digital fluency for teaching is to get an active role as confident authors of their own digital materials. Moreover, Blake (2008) considers that technology can promote authorship, by permitting the publishing and sharing of digital materials produced, and collaboration, as it prompts the creation of learning networks to solve challenging tasks. 
Technology can therefore enhance learning in that it is a space that results from the conversational flow and collaborative interaction between users around a common goal. Through collaborative production of knowledge tools, students can share and generate knowledge in a complex system of mutual dependence between interaction and learning (ALMEIDA, 2008).

Fisher (2011) investigated the perceptions of 19 teachers during a 9month postgraduate training course in a UK university in 2006-7 on the use of information and communication technologies blended with FL teaching. The course aimed to prepare FL High School teachers of French, German, Spanish, and Italian to teach with ICTs. During the 36 weeks of the course, the trainee teachers had been 12 weeks in the university attending workshops on word processing, PowerPoint, internet and interactive whiteboards; observing the staff use of the technology in their own teaching; as well as doing peer-resource sharing and engagement activities in the bulletin board. Afterwards, the teachers went to school to do classroom observation, reflect on their classes through weekly sessions with mentor and group workshops, and to make a written assignment. Data collection for this research was done through semi-structured interviews with the 19 trainee teachers to investigate their perceptions about the ICT and its affordances at the beginning and during the course, how they used digital technology for FL teaching and learning?, besides any cautions about its use and possible projections for future use.

From these interviews, initially it was observed that teachers were nervous, suspicious and skeptical about the benefits and relevance of using ICT for FL teaching and learning??. However, the results showed that the influence of the community of practice around them was an important contextual factor in the adoption of the use of ICT by participants in subject teaching pedagogy. Thus, in an initial context in which there was a lack of facilities combined with the devaluation of the use of ICT, a trainee teacher reported that she felt comfortable in avoiding using ICT. By becoming part of an environment during the course that not only provided resources, but was also formed by co-workers committed to using interactive whiteboards regularly, offering successful examples of technology's fit with FL teaching, the trainee teachers were encouraged to overcome their nervousness and develop their work using the technology. In addition, the departments themselves also began to incorporate technology into their work schemes, generating teaching concepts, centralization of resources and experiences of use that supported teachers' choices of when and where ICT could be used. Thus, in relation to embed and blend digital technology into FL subject pedagogy, it was found that trainees 
had profited from classroom observation, as well as departmental suggestions to develop their own practice, integrating ICT into their teaching (FISHER, 2011). In relation to institutional influence on the success of computersupported language learning, Lamy and Hampel (2007) stress that economic and security decisions can restrict online activities to a platform or prohibit the use of a software. To exemplify the authors say that in France the online chat tool Skype is banned in the educational system for security. This situation applies in some contexts in Brazil in which, in order to use online tools for Computer-mediated Communication as well as social networks, teachers must follow a rather exhausting bureaucratic path.

Added to this, Kessler (2010) reports that in a course he taught on the use of internet resources and web-authoring tools, he was faced with an attitude of distrust from experienced teachers in the use of technology, regarded initially more as an obligation that was not worth spending time to address. However, this first negative perception suffered a change when teachers began to make an exploratory and practical use of ICT applied to FL subjects pedagogy, getting motivated to engage in future activities. Leffa (2005) adds that teachers' computer rejection hides a belief that digital fluency is a gift students are born with and cannot be learned by adults. Based on this matter, the author advises that teacher training courses should therefore focus on working with teachers' fear to use the computer through an active exploration of digital tools to empower them to produce their own materials.

The teaching of a FL, says Kessler (2010), is divided into six categories of skills: reading, listening, writing, speaking, grammar, and culture. Although it is tempting to limit the use of technology only for receptive skills, such as listening and reading, language teachers should be able to use the great potential of digital technologies to address all categories of language skills in a successful manner.

Kessler (2010, p. 359) claims that "becoming familiar with a variety of authoring tools allows teachers to design materials that meet their students' needs", increasing their motivation to participate through the FL. However, besides knowing these tools, it is necessary that the teacher knows how to identify the potential uses of digital tools for their effective inclusion in FL teaching.

According to the FL teachers, technology can play an important role in teaching: vocabulary, through a multi-sensory approach with a myriad of media resources to present new language; pronunciation, with the association between images and sounds from native speakers; listening, through a high quality of 
sound recordings on mp3 files; independence on reading, as a consequence of working on websites and searching of online affairs; oral production and selfassessment, by audio and video recording and editing software, such as Audacity $^{3}$ and Windows Movie Maker; grammar, through cloze exercises available on the Web or created by the teachers through software such as Hot Potatoes; ${ }^{4}$ and culture, by accessing FL authentic websites and media content. In addition, ICT can diminish the anxiety and fear of making mistakes as well as motivate students to improve their language skills in order to better understand authentic materials they find on the Web (FISHER, 2011).

Furthermore, easy-to-use audio and video editing programs, such as Audacity and Windows Movie Maker, can provide a first contact with authentic materials and a rich and varied exposure to FL in a learner-centered instruction integrated to language skills work. Compared with software specifically designed for FL teaching and learning, these broad-application programs are more flexible, fostering a greater variety of uses and promoting a more familiar environment for students to engage in tasks (KESSLER, 2010).

Kessler (2010) states that the use of Windows Movie Maker, by providing a fertile ground to exploration, reflection, creation and sharing of a hypermedia discourse, can serve the goals of FL education, since it promotes the development of an autonomous use of the language together with the ability to formulate and present ideas effectively. It can be used by teachers as provoking material to be used in a follow-up discussion about its content, different points of view, results and alternative scenarios. This software can also be used as instructional material on a particular culture, designed by the teachers with different media.

Moreover, software and web-authoring tools can support studentcentric language projects in which students create their own movies according to their focus of interests, both in language and culture. In these authentic tasks students are encouraged to seek contact with a rich online input and place themselves as authors, exploring their skills and engaging in their learning process in search of independence as language users. Collaborative activities, as Kessler (2010) points out, in which students can reflect on the process of

\footnotetext{
${ }^{3}$ Audacity is a free audio recording and editing software that can be downloaded from the following website: <http://audacity.sourceforge.net/download/>.

${ }^{4}$ Hot Potatoes is a free lesson construction software to build teaching exercises, such as crosswords, gap-fills, cloze, matching, multiple-choice and jumbled exercises. This freeware can be downloaded from the following website: <http://hotpot.uvic.ca/>.
} 
technology and language use, help learners in building critical thinking about their development and learning.

Regarding the construction of digital learning materials, in the Quality Referential for Distance Higher Education of the Ministry Education (BRASIL, 2007), it is stated that teachers should foster interaction and discussion of ideas, as well as focus on the use of relevant information for participation in the world. To do so, it is important to consider the profile and needs of their students and the planned activities in order to meet both teaching and learning goals. Also, Motta-Roth (2010) claims that teachers in continuing education need to develop critical reflection on the processes and products of the FL by learning to communicate through language about language.

Thus, language teaching through technology should focus on tasks of FL exploration, reflection and production as part of the development of joint projects in which both language and technology are means of learning, and products of expression and participation in the Information Society. In addition, the production of digital material must transcend the teacher's hands as just an instructional product to be a motivating way of learning a foreign language as it becomes a tool for students' communication with the virtual world and for their production of knowledge.

\section{The Study}

A case study was designed to analyze the production of pre-service and in service teachers during a training course on the use of digital technologies in FL teaching and learning. The course was promoted by a federal university in southern Brazil. The research questions are reproduced below:

(1) What are the perceptions of FL teachers in initial and continuing training about the importance of digital fluency for their performance and the pedagogical potential of the digital tool Windows Movie Maker?

(2) What are the participants perceptions about the benefits of developing a collaborative reflective task, having Windows Movie Maker in their training?

The training course was created in the Moodle 5 platform (an open source course management system adopted by the university) and had the total period of approximately four months, being divided into four modules. It was

${ }^{5}$ More information on Moodle is available in the following site: $<$ http://moodle.org>. 
a blended online course, where most classes were developed online and only two classes happened in the university's lab, one at the beginning and one at the end of the course. The first class had the objective of introducing the course program, fostering a virtual community formation starting from an on-site experience, and training the teachers to use Moodle for the online classes through the exploitation of their tools (profile, chat, forum). From this first meeting, the trainee teachers had to use the virtual learning environment to collaborate, produce and share knowledge at a distance. Then, at the final class, the trainee teachers returned to the university's lab to present and discuss their final projects. This article focuses on the production of the first three-week module, in which the participants discussed the importance of digital fluency for high quality teaching and how the use of technology can help the process of FL teaching and learning. The following chart summarizes its activities.

\begin{tabular}{|c|c|}
\hline Module 1: Digital Fluency \\
\hline Activities of Module 1 of Digital Fluency \\
\hline - & Self-assessment questionnaire on digital fluency; \\
- & Forum 1 - expectations about the course; \\
& Forum 2 - teacher's digital fluency and the use of digital technologies in FL \\
& teaching and learning; \\
& Collaborative task for the production of a movie over Windows Movie Maker; \\
& Forum 3 - reporting on and exchanging of experiences on task performance \\
& with Windows Movie Maker.
\end{tabular}

In the Digital Fluency module, first of all, an online questionnaire that sought to build a profile of the teachers as to their knowledge in using the computer and the internet was made available. In addition, Forum 1 was opened for the teachers to express their expectations about the course.

So, based on the reading of studies in the field of Computing in Education and the experience of the trainee teachers, Forum 2 was presented to discuss the digital fluency of the teacher and the use of digital technologies in FL teaching and learning. At the end of this module, Windows Movie Maker was explored in order to produce a movie on the digital fluency of the teacher and the potential of this tool in FL teaching and learning. Once finished, teachers should upload their movies on YouTube and post their links on Forum 3. In addition to sharing with the class the movies produced 
collaboratively, this third Forum was created to solve teachers doubts and share their reports on learning experiences using Windows Movie Maker. The focus of this investigation consists of Forum 2 and 3, in addition to the movies produced in groups as the final task for the Digital Fluency module.

The participants were 25 pre-service and in service Brazilian teachers of different foreign languages (English, French, German, and Italian), with an age range from 18 to 59 years, working in public and private regular schools, and private language courses. As to their education, twenty had a teaching degree in Language and Literature (four had also a master's degree) while five were still attending an undergraduate course.

Furthermore, the questionnaire data on digital fluency were analyzed in order to define the profile of the teachers as a group. Thus, the majority of respondents (16) classified their degree of knowledge and skill in computer science in general as intermediate. The main way of access to computer/internet employed by them (according to 17 of the respondents) was the one available at home and school where they worked (7), entering the internet more than once a day (18). Besides, many respondents (19) had already used technological resources in their teaching practice, such as computer, internet and programs, data-show, DVD, CD, camera, recorder and flash drive. In addition, all the participants (25) stated that using computers and the internet is not a difficult task and considered themselves prepared to use computers in the classroom. Regarding the use of technology in the classroom, most of them (21) said to have already joined a social network, but only 10 reported having used a social network in their classes. Added to this, only 2 respondents claimed to use the tools chat and forum in FL teaching.

From these data, it seems that the participants have the knowledge and the basic skills to use the computer and internet, but little use is made of these resources as pedagogical tools, which turns to be the major challenge of the new FL teacher. Furthermore, during the Expectations Forum, the group expressed their wish to learn how to use digital technologies to create motivating lessons that foster the students' desire to learn.

Given this scenario, the module of Digital Fluency sought to open a space for discussion of readings and experiences on the role of FL teachers in the face of technology and the potential of digital technologies for the creation of meaningful tasks for students. The analysis and discussion of the results of this investigation are addressed in the next section. 


\section{Teachers' perspectives on digital fluency}

Forum 2 which focused on the issue of digital fluency as a new competence for the FL teaching and learning process mediated by technology had an intense teacher participation. As for digital fluency for language teaching, Nanci ${ }^{6}$ recognized that this is a competence related not only to knowledge and skills on technology use, but also to the integration of technological resources into clear pedagogical goals from a new teaching paradigm (as discussed previously by PINHO, 2012; MENEZES, 2010; POLONIA, 2003; LEFFA, 2005; 2006), as we can read in Extract 1. Also, we can observe that Nanci establishes a difference between digital fluency for general use and for teaching and learning since the pedagogical goal requires a specific competence to address distance education (NATIONAL RESEARCH COUNCIL, 1999; PAIVA, 1999; PERRENOUD, 2000b; BRASIL, 2000).

\section{Extract 1}

Forum 2. Teacher Nanci.

As the use of digital technology in education is a relatively recent issue, it is necessary that the teacher acquires digital fluency skills, learn and know how to use the technological resources available, which implies, in principle, a paradigm shift for digital immigrants ${ }^{7}$. (...) The teacher should have clear pedagogical goals, because one thing is to use the internet to search and exchange everyday information and the constant communication through social networks, and another different thing is the use of digital technology oriented towards learning a language.

Moreover, participants argued that, in digital terms, a fluent teacher needs to know to integrate knowledge of digital technologies with FL teaching methodology for the planning and mediation of an effective learning, addressing students' profile (BRASIL, 2007; LEFFA, 2005; 2006; KESSLER, 2010; FISHER, 2011), as Janete says in Extract 2.

\footnotetext{
${ }^{6}$ The teachers' names used in this research are fictitious to protect the anonymity of participants.
}

${ }^{7}$ According to Prensky (2001), digital natives were born with the technology, participating in a digital culture, where they are used to receiving information very quickly through multiple channels, as well as constructing their own way of reading through hypertexts. Also, they are nonlinear thinkers and multitask performers; performing many tasks in parallel with the help of learning networks. Compared to 


\section{Extract 2}

Forum 2. Teacher Janete.

I understand that in a digital classroom the teacher must have knowledge and mastery of content, forming, therefore, the skill needed. Being skillful, he will be competent, which is the sum of talent plus skill. The knowledge to link teaching practices with ICT (information and communication technologies) will result in digital fluents, that means to have the competence to use digital resources of the school lab, properly using digital tools, to properly prepare digital lessons, what I am going to teach, for whom and how I am going to do it. How old is the student? What are his interests? How am I going to motivate him?

In Extract 3, Walter pointed out characteristics of the dynamic aspect of digital fluency, considering that knowledge, skills and attitudes modification takes place through performing tasks of content production, promoting, thereby, the teaching and learning process (PERRENOUD, 2000b).

\section{Extract 3}

Forum 2. Teacher Walter.

Digital fluency is the ability of the student to rearrange his concepts/ knowledge, be creative, and, above all, generate information through the range of possibilities that technology provides. So, it is necessary that this arrangement be the flagship of a successful teaching/learning process in that time shows up as the main key to the completion of tasks.

Another point that emerged in the second Forum was raised by Carmen (Extract 4), which begins with the question "How to promote activities that ensure authorship and creativity?”. However, it can be seen in the course of her text that the transformation of education through technology requires the development of authorship and creativity of the teacher himself before the students (LEFFA, 2005; BLAKE, 2008). Thus, it is necessary for the teacher

them, those who were not born in the digital world are called digital immigrants, whose characteristics fit well most of the teachers. Digital immigrants have a linear thinking structure as they need to follow step by step an instruction with a written direction. They usually focus their attention on only one channel of information at a time and slowly. What becomes clear from this definition is that, consequently, there is a difference not only in terms of how learning happens, but also how the teaching and learning processes are seen. 
to stop being a passive user of teaching materials available on the Web and, instead, start assuming the author role of content and activities to be contextualized in the profile of his students.

\section{Extract 4}

Forum 2. Teacher Carmen.

How to promote activities that ensure authorship and creativity? Frequently programs or games are used that only reproduce in a digital form what would be done once on paper, or in recreational activities, maybe even in a higher quality because they are done face-to-face. It is rather important to use media in an authentic manner and not simply reproduce what has been done previously.

Regarding the approach of the use of technology in the classroom, Dinorá (Extract 5) shared a meaningful conclusion about digital fluency. What we see in this extract reflects the awareness of a teacher who had been using technology in a traditional manner, centered on teaching rather than on learning, more vertically oriented and less shared.

\section{Extract 5}

Forum 2. Teacher Dinorá.

My conclusion after the reading is that I must improve significantly my effective participation in the course as well as review my way of approaching the course here as well as in the classroom as an educator, because I'm still following traditional approaches and I'm not being a facilitator as I thought I was before. It is necessary to plan new activities that can actually allow my students to interact with me and their classmates so that we can build together new knowledge with the use of IT (information technology).

The context of education is another factor that may influence the use of technology in the FL classroom (LAMY; HAMPEL, 2007; KESSLER, 2010; FISHER, 2011). Regarding the difficulties in the use of technology in FL teaching in public schools, teachers listed as negative factors: the heavy weekly schedule; the limited time for lesson planning; reduced class time; the lack of harmony with the school institution, peers and parents about the importance of using the computer lab; the lack of a technical team to support the teaching practice; the lack of equipment maintenance; and low internet speed. As to private language schools, teachers said to have the technological resources available, but they also suffered from the lack of time to plan lessons, 
the reduced class time, and with the bureaucracy to access social networks that were not authorized by the school.

On the other hand, the participants mentioned several private initiatives of their own and their colleagues to develop student projects involving mobile technologies, video editing programs, blogs and social networks, showing that it is possible to upgrade the FL teaching. In this regard, the participant Mateus demonstrates, in Extract 6, the desire to see technology integrated into the curriculum and the necessary institutional support to allow high quality FL education to happen.

Extract 6

Forum 2. Teacher Mateus.

Hopefully, soon, the technological resources can enter a school curriculum as a duty of every teacher to offer any of these possible resources and this teacher will have the necessary training and the available time to perform his activities properly and with more tranquility (planning, preparation, implementation and evaluation of the activity).

It was also mentioned that the teacher who is willing to be a facilitator of the learning process in the virtual environment should master not only a particular FL, but also the technological resources used in a task, knowing the operational and potential problems that may occur during the activity. Added to this, it was observed that the teacher's role is to guide students to learn how to use technology for learning. Moreover, the teacher's mediation should foster, through questions about knowledge and actions, the transformation of the flood of available information on the internet into meaningful knowledge for students. According to participants, it is also the teacher's responsibility to promote critical, autonomous, and authoring use of technology so that students take an active role on their learning (LEFFA, 2005; BLAKE, 2008; KESSLER, 2010), as reminded by the participant Renato in Extract 7. 
Extract 7

Forum 2. Teacher Renato.

As for the video, it is very interesting also to address the evolution of information, reinforcing our role as mediators of information in the classroom, and to show students what they can do with it, besides enjoying, toying and playing. They need to criticize, rethink, create, modify and promote the information culture in a responsible manner.

When asked about the use of technology in the classroom, most of the teachers (18) replied that the school had a computer lab. It was observed, however, that many of the examples described by teachers in the Forum were related to a more passive use of technology, turning it into an input for FL tasks (as one possible use proposed by Kessler, 2010). Reported examples consist of tasks in which students would interact with the technology just by viewing YouTube videos, music, content from Web pages and presentations to have a possible discussion and/or a listening comprehension exercise. However, it is worth considering that, although these tasks do not allow much interaction, as one participant pointed out, the presentation of digital materials recorded by the teacher that do not require an internet access remains as the only opportunity of contact with technology possible in certain public schools.

However, there are social networks for sharing texts, images, videos, posters; collective web-authoring tools, web oral and written chats, with or without video, and forums that are already part of the lives of many students and which teachers can explore as teaching and learning tools. YouTube, ${ }^{8}$ for example, is a social network formed by worldwide users that allows them to post videos and comments. From this perspective, YouTube could be used to encourage learners' authorship, autonomy and creativity through the sharing of collaboratively produced videos and online discussions with the entire class.

Moreover, in Extract 8, Vânia asserts that, in order to build motivating tasks, the teacher should start working from the profile of his students to promote the use of technology and language as a meaningful experience of participation in the Information Society.

${ }^{8}$ YouTube can be accessed by the following address: <http://www.youtube.com/>. 


\section{Extract 8}

Forum 2. Teacher Vânia.

I believe that students today seek and are interested in tasks that are relevant and useful in their lives, something that gives them experience and expertise in some way. It is from this perspective that the technological interaction applies and it is in this context that technology linked to education becomes relevant. Through activities that are at the same time attractive, challenging and relevant to the experience of students, the Foreign Language teacher may be able to keep his students interested and motivated for longer.

It becomes clear, therefore, the importance of the provision of continuing training courses for the use of technology in language teaching that enables teachers to reflect on the potential of technology as well as on their experiences with its use, increasing, thereby, their teaching possibilities.

In the following section, the data generated in the collaborative task of producing a movie with Windows Movie Maker are discussed with emphasis on the teachers' perceptions about the pedagogical use of this tool and the contribution of the task to their training.

\section{The teaching potential of Windows Movie Maker}

The final task of the module digital fluency was the construction of a movie in groups of three with Windows Movie Maker tool, as shown in FIG. 1 , on the challenges of language teacher in relation to computer mediated education. Windows Movie Maker ${ }^{9}$ is an easy-to-use video creating/editing software, which offers various features like transition and video effects, custom texts and audio. It allows the edition of authentic materials, such as videos, images, music, audio, and the recording of voice narration.

\footnotetext{
${ }^{9}$ Windows Movie Maker is a Windows standard software that is part of Windows Live essentials initiative. It can be accessed through the following address: <http:// windows.microsoft.com/pt-br/windows-live/essentials-home>.
} 


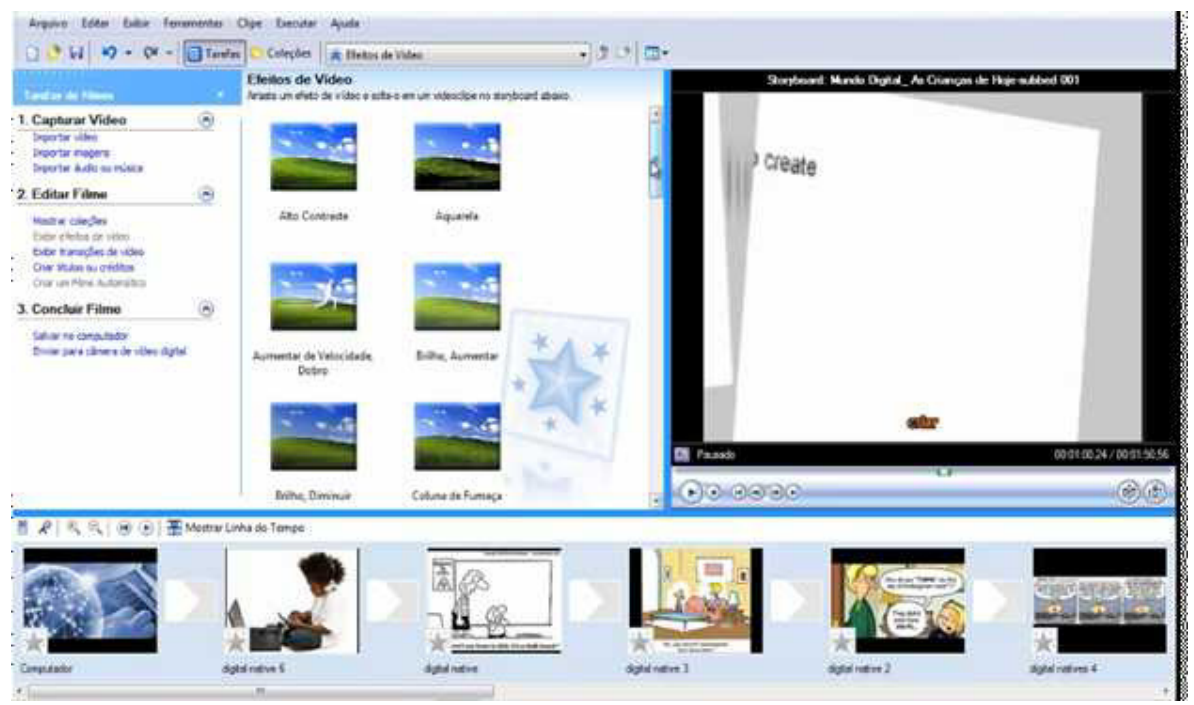

FIGURE 1: Windows Movie Maker 2.6

To accomplish the task, it was suggested that teachers addressed the following topics:

- digital fluency as a new competence for teachers of foreign languages;

- teaching mediation and the role of language teacher in technology mediated education; and

- possible uses of Windows Movie Maker in FL teaching and learning.

As to the use of the main available resources of this program, the trainee teachers were asked to create movies with at least 20 slides, including introductory title, titles and credits, transition and video effects. Besides, the groups could use images, audio and video. To support their production, a basic tutorial ${ }^{10}$ for the program designed for this module on YouTube was released. Finally, the movies should be posted on YouTube and their links posted in Forum3.

The materials produced by the teachers represented a building process of great effort and time investment for research and group negotiation. According to the guidelines of the task, the videos addressed digital fluency,

${ }^{10}$ The tutorial produced for the course is available on YouTube at the following address: <http://youtu.be/sQWYUQ0zPag>. 
the teacher's role and Windows Movie Maker uses with examples of projects done through its various resources. Also, the videos talked to the teachers themselves, motivating them to assume a mediating role between the learner and the learning environment. Still, they focused on the use of technology in creating enjoyable tasks for the students and the importance of teachers developing digital fluency to be mediators of the learning process. It can be inferred from their content that the discussions in the Forums and the reading contents were appropriated in the video production, suggesting that there was knowledge construction. It is also important to point out that the movies showed not only the opinion of teachers, but also their creativity in the use of images and the value given to the suggested references.

Through the analysis of Forum 3 and the movies, it was observed that Windows Movie Maker was seen as a digital tool that can promote FL learning by creating opportunities for language expression with the use of various media, such as text, images, videos, audio and music. In addition, teachers considered that this tool can foster the development of FL communication through the work with oral and written production and comprehension, as shown in the statement by Amanda.

\section{Extract 9}

Forum 3. Teacher Amanda.

Using Movie Maker offers an excellent opportunity to work with written and oral production, the use of vocabulary including slang and idioms, the work with the formal structure and the metalinguistic reflection, pronunciation, intonation and expression, listening comprehension and accent identification.

The tool requires the appropriation of its resources, which can motivate language learners to also develop their digital fluency for participation in the virtual world. It also favors the production of material that can be conveyed in social networks like YouTube, which can offer an authentic context for meaningful learning.

In the reports containing suggestions and experiences, the trainee teachers pointed out several possibilities of using Windows Movie Maker tool in FL production of collaborative tasks, such as subtitling videos, making presentations of specific topics, creating advertisements, constructing narratives, and producing a news program.

According to participants, the collaborative task of building the video at a distance brought contributions to their training, since it made the effective 
use of Windows Movie Maker possible with the discovery of its resources as well as the establishment of partnerships with colleagues, as stated by Tamara in Extract 10.

\section{Extract 10}

Forum 3. Teacher Tamara.

Overall, the movie production was enriching, because I personally did not know Movie Maker and I had no idea how to use the tool. I confess that putting images, texts, sounds and videos is relatively simple. The difficulty lies in adjusting the time of the slides transition to the use of several songs in the same video and, at the right time, adding another video to ours. Difficulties that were being gradually solved by our email exchange and posts in the forums. $[\ldots]$

In this sense, a task like this shows that we can indeed do a good job at a distance, in groups, but we have to rely on a great deal of autonomy and motivation to make it really effective. As teachers, we need to know the technology very well to provide support to our students and to do a good job with the digital tools.

It is noted that the task completion promoted reflection by teachers on their knowledge, skills and attitudes regarding the technical and educational use of technology. It was argued, therefore, that the teacher must develop an autonomous, responsible and active attitude so that he can promote and mediate learning situations through technology (PERRENOUD, 1999, 2000b), as pointed out by Mateus, one of the teachers involved.

\section{Extract 11}

Forum 3. Teacher Mateus.

To finish my contributions in this work, I would emphasize that it is possible to perform a work in Distance Education through the exchange of material by virtual means, and, thereby, build the knowledge that we so much seek to our training and our students. It is possible to establish relationships, connections, critique and research to construct new information, reflect on the actions and, mainly, learn effectively and meaningfully. But, as we discuss in our movie, for this to happen, autonomy, responsibility and dedication are required.

Another point worth mentioning is that the teachers saw concretely what could be offered to their students, and how technology could foster the learning process. By putting students' shoes, teachers began to see technology 
as an ally to promote FL learning and to become authors of digital materials, realizing the benefits of teamwork, as Barbara mentions in Extract 12.

\section{Extract 12}

Forum 3. Teacher Barbara.

On the one hand, it was a great challenge to work online in group: our group peers did not know one another, besides having very diverse schedules and commitments. On the other hand, it was a great opportunity to exchange knowledge, experiences, make new friends... and, in my case, I can say that the task developed a lot of my self-confidence in relation to using digital tools; a real quantum leap for my teaching practice!

From these data, we conclude that the task of producing digital material contributed to the training of modern foreign language teachers by promoting the development of digital fluency, since it allowed the effective use of Windows Movie Maker with the discovery of its resources. It also promoted autonomy and authorship in FL teaching through the challenge of taking a stand before readings and discussions about the creative use of media. It enhanced collaboration through the perception of the benefits of team work, understood as essential to teaching and learning from a sociocultural perspective (SWAIN, 2001). Finally, it encouraged a critical view of their knowledge, skills and attitudes regarding the technical and pedagogical use of technology and prompted the construction of relevant tasks from the perspective of the students.

It is hoped that from this experience teachers will make use of the Web to publish and share project results with students, and establish learning and research networks with colleagues from other institutions in Brazil and the world.

\section{Concluding Remarks}

The results suggest that digital fluency for FL teaching consists of the integration, implementation and modification of knowledge, skills and attitudes about the educational use of technology for planning lessons through collaborative production. Thus, the language teacher should know the potential of digital technologies, adding to them clear educational objectives and methods in order to be able to create tasks that match their teaching conceptions. For an effective performance, the FL teacher needs to review his practice, seeking to develop his authorship and creativity in the production of his own digital material. 
The proposed collaborative task for the production of digital material sought to motivate FL teachers to make use of technology as a pedagogical tool in the Information Society, developing, as a result, their autonomy and authorship. In addition, it had the objective of promoting a perspective of technology use for collaborative learning, since the construction of the movies on Windows Movie Maker was itself a concrete example of how to use it i.e., as a means of creative expression and production of technology and language with media support. Additionally, Windows Movie Maker was considered a digital tool to be used in students-centric learning tasks that allows the exploration and development of skills on language and technology use from a variety of media expressions. The collaborative production of the movie on digital fluency in FL teaching enabled the trainee teachers to reflect on the challenges of using technology in education, the need to consider the profile of their students and change their teaching approach.

Finally, on the way to digital fluency, it is noteworthy that the teaching context can jeopardize the teaching practice, taking into account that the lack of institutional support can be considered as a major impact. Nevertheless, for the use of technology in the classroom not to be an individual and single event in a curriculum that presents itself as distant from the changes in society in the technology era, a collaborative bridge has to be created not only between teachers and machines, or between teachers and learners through machines, but in a higher level between higher education institutes, schools and the government.

\section{References}

ALMEIDA, Elizabeth Biaconcini. Tecnologias trazem o mundo para a escola. Jornal do Professor, 2008. Available at: <http://portaldoprofessor.mec.gov.br/ conteudoJornal.html?idConteudo=37>. Retrieved November 14, 2010.

BENSON, Phil. Teaching and Researching Autonomy in Language Learning. Malaysia: Pearson Education Limited, 2001. 272 p.

BLAKE, Robert J. Brave New Digital Classroom: Technology and Foreign Language Learning. Washington, D. C.: Georgetown University Press, 2008. $240 \mathrm{p}$.

BONILLA, Maria Helena. O Brasil e a Alfabetização Digital. Jornal da Ciência, Rio de Janeiro, 13 de abril de 2001, p. 7. Available at: <http://www.faced.ufba. br/ -bonilla/artigojc.htm $>$. Retrieved April 3, 2009. 
BRASIL. Ministério da Educação. Secretaria da Educação a Distância. Referenciais de qualidade para a educação superior a distância. Brasília, DF, agosto de 2007.31 p. Retrieved December 1, 2010. Available at: <http://portal.mec.gov.br/index.php? option $=$ com_content\&view=article\&id=12907: legislacoes\&catid=70:legislacoes $>$. BRASIL. Ministério da Ciência e Tecnologia. Sociedade da Informação no Brasil: Livro Verde. TAKAHASHI, T. (Org.). Brasília, DF, 2000. 195 p. Retrieved December 1, 2010. Available at: <http://www.mct.gov.br/index.php/content/ view/18878.html>.

DOLZ, Joaquim; OLLAGNIER, Edmée. O enigma da competência em educação. Porto Alegre: Artmed, 2004. 232 p.

FISHER, Linda. Trainee teacher's perceptions of the use of digital technology in the languages classroom. In: EVANS, Michael (Ed.). Foreign Language Learning with Digital Technology. New York: Continuum, 2011. p. 60-79.

HALL, Joan Kelly. Methods for Teaching Foreign Language: Creating a Community of Learners in the Classroom. Ohio: Merrill Prentice Hall, 2001. 273 p.

JONASSEN, David H; LEE, ChweeBeng; YANG, Chia-Chi; LAFFEY, James. The Collaboration Principle in Multimedia Learning. In: MAYER, Richard E. (Ed.). The Cambridge Handbook of Multimedia Learning. Cambridge: Cambridge University Press, 2005. p. 247-270.

KESSLER, Greg. Integrating Technology in the Foreign Language Classroom. In: CENNAMO, K. S.; ROSS, J. D. ERTMER, P. A. Technology Integration for Meaningful Classroom Use: A Standards-Based Approach. China: Wadsworth, 2010. p. 351-367.

LAMY, M. N.; HAMPEL, R. Online Communication in Language Learning and Teaching. Research and Practice in Applied Linguistics. New York: Palgrave MacMillan, 2007. 272 p.

LANTOLF, J. P. (Ed.) Sociocultural Theory and Second Language Learning. Oxford: Oxford University Press, 2000. 296 p.

LANTOLF, J. P. Sociocultural Theory and L2: State of the Art. SSLA, v. 28, p. 67-109, 2006.

LEFFA, V. Uma ferramenta de autoria para o professor: O que é e o que faz. Letras de Hoje, 41 (144), p. 189-214, 2006.

LEFFA, V. On becoming digitally literate: the production of computer-mediated materials by language teachers. In: CONVENÇÃO DA ASSOCIAÇÃO DOS PROFESSORES DE INGLÊS DO RIO GRANDE DO SUL, 2005. Porto Alegre, Teaching and Learning Processes. Porto Alegre: PUC-RS, 2005. CD. 
LIMA, Marília dos Santos. Collaborative tasks and learning occasions in English as a foreign language. Revista Brasileira de Linguistica Aplicada (Impresso), v. 11, p. 48-61, 2011.

LIMA, Marília dos Santos; COSTA, Patrícia da Silva Campelo. O diálogo colaborativo como ação potencial para a aprendizagem de línguas. Trabalhos em Linguistica Aplicada (UNICAMP), v. 49, p. 167-184, 2010.

MENEZES, Vera Lúcia. Aprendendo inglês no Ciberespaço. In: MENEZES, Vera Lúcia. (Ed.). Interação e Aprendizagem em Ambiente Virtual. Belo Horizonte: Editora UFMG, 2010. p. 319-358.

MOTTA-ROTH, Désireé. De receptor de informação a construtor de conhecimento: o uso do chat no ensino de inglês para formandos de Letras. In: MENEZES, Vera Lúcia (Ed.). Interação e Aprendizagem em Ambiente Virtual. Belo Horizonte: Editora UFMG, 2010. p. 269-289.

NATIONAL RESEARCH COUNCIL COMMITTEE ON INFORMATION TECHNOLOGY LITERACY. Being fluent with information technology. Washington, D. C.: National Academy Press, 1999. 128 p. Available at: <http:/ /books.nap.edu/html/beingfluent>. Retrieved April 3, 2009.

NICOLAIDES, Christine Siqueira. A busca da aprendizagem autônoma de língua estrangeira no contexto acadêmico. Phd Thesis. Porto Alegre: UFRGS, 2003.

PAIVA, Vera Lúcia Menezes de Oliveira e. Diários online na aprendizagem de língua inglesa mediada por computador. In: MARI, Hugo et al. (Ed.). Fundamentos e Dimensóes da Análise do Discurso. Belo Horizonte: Carol Borges, 1999. p. 359-378. Available at: <http://www.veramenezes.com/diarios.htm>. Retrieved May 5, 2010.

PERRENOUD, Philippe. Construindo competências. Nova Escola (Brasil), p. 19-31, September 2000a. Available at: < http://www.unige.ch/fapse/SSE/ teachers/perrenoud/php_main/php_2000/2000_31.html>. Retrieved August 10, 2011.

PERRENOUD, Philippe. Construir as competências desde a escola. Porto Alegre: Artes Médicas Sul, 1999. 90 p.

PERRENOUD, Philippe. De uma metáfora a outra: transferir ou mobilizar conhecimentos? In: DOLZ, Joaquim; OLLAGNIER, Edmée. O enigma da competência em educação. Porto Alegre: Artmed, 2004. p. 47-64.

PERRENOUD, Philippe. Dez novas competências para ensinar. Porto Alegre: Artes Médicas Sul, 2000b. 162 p.

PERRENOUD, Philippe; THURLER, Monica Gather. As competências para ensinar no século XXI: a formação dos professores e o desafio da avaliação. Porto Alegre: Artmed, 2002. 176 p. 
PINHO, Isis da Costa, LIMA, Marília dos Santos. A fala privada no desenvolvimento de tarefas colaborativas em inglês. Calidoscópio (UNISINOS), v. 8 , p. $38-48,2010$.

PINHO, Isis da Costa. A autonomia na aprendizagem de L2. In: SEMINÁRIO INTERNACIONAL EM LETRAS (LINGUAGEM, SUJEITO, REPRESENTAÇÃO), 8, Centro Universitário Franciscano - UNIFRA, Santa Maria, 2008. PINHO, Isis da Costa. Collaborative tasks in English as a foreign language in virtual environment. In: CONGRESSO INTERNACIONAL DA ABRAPUI (LANGUAGE AND LITERATURE IN THE AGE OF TECHNOLOGY), 3, Federal University of Santa Catarina (UFSC), Florianópolis, Santa Catarina, Brazil, 2012.

PLASS, Jan. L.; JONES, Linda C. Multimedia Learning in Second Language Acquisition. In: MAYER, Richard E. (Ed.). The Cambridge Handbook of Multimedia Learning. Cambridge: Cambridge University Press, 2005. p. 467-488. POLONIA, E. Parâmetros para procedimentos pedagógicos na aprendizagem de inglês como lingua estrangeira em uma rede telemática. 2003. (PhdThesis). Postgraduate Program of Computers in Education/ Federal University of Rio Grande do Sul (UFRGS), Porto Alegre, Brazil.

PRENSKY, M. Digital Natives, Digital Immigrants, 2001. 6 p. Available at: <http:// www.marcprensky.com/writing/Prensky\%20-\%20Digital\%20Natives, \%20 Digital\%20Immigrants\%20-\%20Part1.pdf>. Retrieved April 10, 2010.

SWAIN, M. Communicative Competence: Some Roles of Comprehensible Input and Comprehensible Output in its Development. In: GASS, S.; MADDEN, C. (Ed.). Input in Second Language Acquisition. Cambridge, MA: Newbury House Publishers, 1985. p. 235-256.

SWAIN, M. Integrating Language and Content Teaching Through Collaborative Tasks. The Canadian Modern Language Review, v. 58, n. 1, p. 44-63, set. 2001. SWAIN, M. Languaging, agency and collaboration in advanced second language learning. In: BYRNES, H. (Ed.). Advanced language learning: The contributions of Halliday and Vygotsky. London, UK: Continuum, 2006. p. 95-108.

SWAIN, M. The Output Hypothesis and Beyond: Mediating Acquisition Through Collaborative Dialogue. In: LANTOLF, J. P. Sociocultural Theory and Second Language Learning. Oxford: Oxford University Press, 2000. p. 97-114. SWAIN, M. Three Functions of Output in Second Language Learning. In: COOK, G.; SEIDLHOFER, B. (Ed.) Principle and Practice in Applied Linguistics: Studies in honor of H. G. Widdowson. Oxford: Oxford University Press, 1995. p . 125-144. 
VYGOTSKY, L. O Instrumento e o símbolo no desenvolvimento da criança. In: VYGOTSKY, L. A formação social da mente: $O$ desenvolvimento dos processos psicológicos superiores. São Paulo: Martins Fontes, 1998. p. 25-40.

VYGOTSKY, L. S. Mind in Society: the Development of Higher Psychological Processes. Cambridge, MA: Harvard University Press, 1978. 159 p.

VYGOTSKY, L. S. O desenvolvimento da percepção e da atenção. In: VYGOTSKY, L. S. A. Formação social da mente. São Paulo: Martins Fontes, 2003. p. $41-49$.

VYGOTSKY, L. S. The Collected Works of L. S. Vygotsky.V.1. Thinking and Speaking. New York, N.Y.: Plenum Press, 1987. 396 p.

VYGOTSKY, L. S. Thought and Language. Cambridge, MA: MIT Press, 1986. $344 \mathrm{p}$.

WOOD, D.; BRUNER, J. S.; ROSS, G.The Role of Tutoring in Problem Solving.Journal of Child Psychology and Psychiatry, n. 17, p. 89-110, 1976.

ZABALA, Antoni; ARNAU, Laia. Como aprender e ensinar competências. Porto Alegre: Artmed, 2010, 197 p.

Recebido em 21/98/2012. Aprovado em 20/02/2013. 